\title{
Werken naar vermogen: vermogen om te werken
}

\author{
Citation for published version (APA):
}

Nijhuis, F. J. N. (2011). Werken naar vermogen: vermogen om te werken. Maastricht University. https://doi.org/10.26481/spe.20110512fn

Document status and date:

Published: 12/05/2011

DOI:

10.26481/spe.20110512fn

Document Version:

Publisher's PDF, also known as Version of record

\section{Please check the document version of this publication:}

- A submitted manuscript is the version of the article upon submission and before peer-review. There can be important differences between the submitted version and the official published version of record.

People interested in the research are advised to contact the author for the final version of the publication, or visit the DOI to the publisher's website.

- The final author version and the galley proof are versions of the publication after peer review.

- The final published version features the final layout of the paper including the volume, issue and page numbers.

Link to publication

\footnotetext{
General rights rights.

- You may freely distribute the URL identifying the publication in the public portal. please follow below link for the End User Agreement:

www.umlib.nl/taverne-license

Take down policy

If you believe that this document breaches copyright please contact us at:

repository@maastrichtuniversity.nl

providing details and we will investigate your claim.
}

Copyright and moral rights for the publications made accessible in the public portal are retained by the authors and/or other copyright owners and it is a condition of accessing publications that users recognise and abide by the legal requirements associated with these

- Users may download and print one copy of any publication from the public portal for the purpose of private study or research.

- You may not further distribute the material or use it for any profit-making activity or commercial gain

If the publication is distributed under the terms of Article $25 \mathrm{fa}$ of the Dutch Copyright Act, indicated by the "Taverne" license above, 
Maastricht University

Prof. dr. F.J.N. Nijhuis

Faculty of Psychology and Neuroscience

\section{Werken naar vermogen: vermogen om te werken}


Werken naar vermogen:

vermogen om te werken 


\section{Colofon}

Ontwerp en print: Océ Business Services, Maastricht

ISBN: 978-90-5681-364-2

NUR: 770

Alle rechten voorbehouden. Niets uit deze uitgave mag worden verveelvoudigd, opgeslagen in een geautomatiseerd gegevensbestand of openbaar gemaakt worden, zonder voorafgaande schriftelijke toestemming van de auteur of uitgever. 


\section{Werken naar vermogen: vermogen om te werken}

Rede

Uitgesproken bij de aanvaarding van de Atlant-leerstoel Inclusieve (Arbeids)organisatie aan de Faculty of Psychology and Neuroscience van de Universiteit Maastricht

Maastricht, 12 mei 2011

Prof. Dr. F. J. N. Nijhuis 


\section{Inleiding}

Honderd jaar geleden verscheen The Principles of Scientific Management van Frederick Taylor. In deze studie laat hij op basis van bewegings- en tijdsstudies zien dat complexe taken opgebroken kunnen worden in meer elementaire taken. Tevens toont hij aan dat het organiseren van werkprocessen op basis van deze elementaire taken tot een aanzienlijke efficiency verbetering leidt. Deze studie heeft lang een belangrijke rol gespeeld in de Arbeids- en Organisatiepsychologie. Niet alleen vanwege zijn onderzoeksmethodieken maar vooral omdat de resultaten daarvan decennialang de organisatie van de arbeid hebben beïnvloed. Enerzijds omdat daarmee de grondslag werd gelegd voor de lopende band arbeid en anderzijds vanwege de negatieve gevolgen voor de satisfactie en motivatie van werknemers; eentonige activiteiten blijken voor veel werknemers niet motiverend en uitdagend te zijn.

Deze constatering vormde de grondslag voor veel onderzoek binnen de Arbeids- en Organisatiepsychologie naar de eisen waaraan gezonde functies moeten beantwoorden. Een belangrijke conclusie die uit al deze onderzoeken kan worden getrokken, is dat het organiseren van werkprocessen op één manier nooit kan beantwoorden aan de diversiteit van de mogelijkheden, capaciteiten en wensen van werknemers. Sommige mensen blijken goed in staat te zijn om te werken in meer eenvoudige functies, terwijl andere werknemers gemotiveerd worden door meer complexe en uitdagende functies. De juiste man of vrouw op de juiste plaats is dan ook de kern van de personeelspsychologie; het is de uitkomst van het wervings- en selectieproces voor nieuwe medewerkers.

Bij het ontwerpen van werkprocessen lijkt het er echter op dat deze behoefte aan diversiteit in functies in de afgelopen jaren ondergesneeuwd is geraakt. Ten onrechte zoals ik in deze rede zal laten horen. Het niet uitgaan van diversiteit sluit namelijk een aantal mensen uit van reguliere arbeid.

Bepalend voor de passendheid van een functie is de overeenkomst tussen de eisen die een functie stelt en de competenties en mogelijkheden van de potentiële werknemer. Om tot een goede matching te komen zijn binnen de arbeids- en organisatiepsychologie aan de ene kant assessmentinstrumenten ontwikkeld om de mogelijkheden en kwaliteiten van een potentiële werknemer te beoordelen en anderzijds worden functies beschreven en gecreëerd die het beste voldoen om de noodzakelijke werkprocessen in een optimale bezetting te realiseren. 
Binnen de arbeids- en organisatiepsychologie wordt daarbij uitgegaan van de gezonde werknemer en van functies zoals deze binnen de organisatie, het bedrijf gegroeid zijn of zoals deze beschreven worden vanuit het functiestructuur zoals die in een organisatie bestaat. Naast het bepalen van de huidige fit tussen de mogelijkheden en competenties van de potentiële werknemer, wordt vaak ook getracht om inzicht te verwerven in de groei- en ontwikkelmogelijkheden van de werknemer naar de toekomst. Dit selectieproces is gericht op het vinden van de werknemer die het beste beantwoordt aan de eisen van de functie. Deze benadering leidt er toe dat een werknemer die om de een of andere reden niet voldoet aan de functie-eisen, afvalt voor de betreffende functie. Dit betekent voor werknemers met een beperking dat de gewone selectie- en aannameprocedures niet voldoen; daarvoor is een ander perspectief nodig en dient ook andere kennis vergaard te worden. In deze rede sta ik stil bij de wijze waarop de realisatie van de mogelijkheden van mensen met een beperking waargemaakt kan worden, de wijze waarop organisaties in staat zijn om daadwerkelijk op een goede wijze de mogelijkheden van mensen met een grote afstand tot de arbeidsmarkt kunnen benutten en organisaties kunnen uitgroeien tot inclusieve organisaties.

Dit vraagstuk, het onvermogen om te komen tot een benutting van de mogelijkheden van mensen met een grote afstand tot de arbeidsmarkt, speelt zich, zoals ik zal laten zien, niet alleen af op microniveau tussen werkgever en werknemer. Ook op macroniveau, op het niveau van de samenleving, is er een misfit tussen de arbeidsvermogens van mensen en de mogelijkheden om deze vermogens te benutten. De kernvraag is dan ook:

Wat kan de bijdrage vanuit de wetenschap, vanuit de Arbeids- en Organisatiepsychologie, zijn om een inclusieve arbeidsorganisatie te realiseren met als uiteindelijke doel om te komen tot een optimale arbeidsparticipatie van mensen met een beperking?

Uitgangspunt daarbij is dat allereerst een maatschappelijk beleid ontwikkeld moet worden dat gericht is op het actief laten participeren van alle burgers naar vermogen. Beleidsontwikkeling alleen is echter onvoldoende, het is ook van belang dat het werk zo georganiseerd is dat inclusief werken ook daadwerkelijk mogelijk is. Ik zal laten zien door welke processen, functies zich steeds meer op een zodanige wijze ontwikkeld hebben, dat zij minder geschikt zijn geworden voor mensen 
met een beperking en ook hoe deze processen omgedraaid kunnen worden.

Om te komen tot duurzame plaatsing van mensen met een beperking is ook de rol van de werkgever en de werknemer van belang. Op basis van de kennis die in de afgelopen jaren verkregen is, kan aangegeven worden op welke wijze werkgever en werknemer ondersteund kunnen worden om deze gewenste verandering te bereiken. Deze thematiek, het onderzoek naar arbeidsprocessen, -inhoud en -omstandigheden die tegemoetkomen aan de mogelijkheden van werknemers aan de onderkant van de arbeidsmarkt,en het gedrag van werkgever en werknemers om duurzame arbeidsplaatsen voor deze groep te creëren, zal centraal staan in mijn onderzoeksagenda voor de komende jaren.

\section{Waarmaken van vermogens op maatschappelijk niveau}

Op maatschappelijk niveau is bekend dat de arbeidsparticipatie van mensen met beperkingen vanwege gezondheidsklachten of een aandoening achterblijft bij de arbeidsparticipatie van mensen zonder beperking. In zijn algemeenheid geldt dat van de mensen die beperkingen ervaren in de werksituatie vanwege gezondheidsproblemen, slechts de helft daadwerkelijk deelneemt aan arbeid, terwijl van de mensen zonder beperkingen ruim 70\% participeert aan arbeid (OECD, 2010). De arbeidsparticipatiegraad van mensen met een beperking in Nederland is $44 \%$, terwijl de participatiegraad van mensen zonder beperkingen $80 \%$ is. De participatiegraad van mensen met een beperking komt overeen met het OECD gemiddelde. Ook het werkloosheidspercentage van mensen met een beperking is bijna drie maal zo hoog als het werkloosheidspercentage van mensen zonder een beperking. Ondanks dat het beleid in Nederland in de afgelopen jaren gericht was op een toename van de arbeidsparticipatie van mensen met een beperking moeten we constateren dat de daadwerkelijke arbeidsparticipatie van mensen met een beperking in de eerste tien jaren van deze eeuw niet gestegen is. Deze constatering geldt ook voor de andere landen binnen de EU. De krappere arbeidsmarkt tot 2008 en dus een relatief grote vraag naar arbeid heeft dus niet automatisch tot een grotere arbeidsparticipatie van mensen met een beperking geleid. Daaruit is tevens af te leiden dat de oorzaken van non-participatie van een meer structurele aard zijn en dat de lagere participatiegraad van mensen met een beperking niet een vorm van verborgen werkloosheid is. 
Bij het analyseren van structurele maatschappelijke aspecten die de participatie van mensen met een beperking op maatschappelijk niveau beïnvloeden, richt ik mij op twee relevante aspecten die direct gerelateerd zijn aan het realiseren van de arbeidsmogelijkheden van mensen met een grote afstand tot de arbeidsmarkt. Op de eerste plats betreft het de maatschappelijke positie van mensen met een grote afstand tot de arbeidsmarkt en op de tweede plaats de mogelijkheden die de arbeidsmarkt biedt om deze mogelijkheden om te zetten in arbeid.

\section{Maatschappelijke positie van mensen met een grote afstand tot de arbeidsmarkt}

Het overheidsbeleid in Nederland heeft zich tot het begin van dit millennium gericht op het verzorgen van een uitkering aan mensen met een beperking en in mindere mate op participatiebevordering. Ondanks de wijzigingen in de sociale zekerheid gericht op het vergroten van de arbeidsparticipatie behoort Nederland nog steeds tot een van de landen met het hoogste aantal arbeidsongeschiktheidsuitkeringen (OECD, 2010). De sociale welvaartsstaat met zijn goede arbeidsongeschiktheidsregelingen heeft er in dat opzicht aan bijgedragen dat mensen met een beperking geëxcludeerd werden van arbeidsdeelname of arbeid voor hen op een niet reguliere, speciale wijze geregeld werd in het kader van de door de overheid gefinancierde sociale werkvoorziening. Nederland heeft verhoudingsgewijs het meeste aantal mensen dat werkzaam is in een beschermde werkomgeving, de Sociale Werkvoorziening (Visier, 1998; Commissie fundamentele herbezinning WSW, 2008). In tegenstelling tot het beleid in bijvoorbeeld de Angelsaksische landen om mensen met ernstige beperkingen zoveel mogelijk regulier, bij gewone werkgevers te plaatsen, werd in Nederland een uitzonderingspositie gecreëerd voor mensen met ernstige beperkingen. Doel was vooral mensen te beschermen tegen de zwaardere eisen vanuit de reguliere werksituatie en hen te beschermen tegen armoede. Dit leidt er toe dat midden jaren negentig van de vorige eeuw het aantal mensen met een arbeidsongeschiktheidsuitkering is gestegen tot tegen het miljoen. Dit brengt zeer hoge maatschappelijke kosten met zich mee en de noodzaak om het aantal mensen met een beperking die een beroep doen op een arbeidsongeschiktheidsregeling terug te dringen. Verandering in de toeleiding, door een vergroting van de verantwoordelijkheid van werkgever en werknemer (Wet Verbetering Poortwachter) en veranderingen in de criteria om aanspraak te mogen maken op een arbeidsongeschiktheidsuitkering, leiden tot 
een eerste afname van het aantal mensen dat een beroep doet op een arbeidsongeschiktheidsuitkering.

Tegelijkertijd is er na de invoering van een arbeidsongeschiktheidswetgeving voor jongeren met een beperking een snelle stijging te zien van het aantal jongeren dat vanwege een beperking, aanspraak maakt op een Wajong-uitkering. Gevolg is dat de arbeidsparticipatie van mensen met een beperking nog steeds achterblijft bij de maatschappelijk hogere noodzaak tot deelname aan het arbeidsproces.

In deze rede beperk ik mij tot de arbeidsmogelijkheden voor diegenen die zonder ondersteuning niet in staat zijn om aan het werk te komen en te blijven en die zelfs met die ondersteuning niet in staat zijn om zelfstandig het minimumloon te verdienen. De nieuwe regeling voor de onderkant van de arbeidsmarkt, die door het huidige kabinet wordt voorbereid, heeft met name betrekking op deze groep.

Geschat kan worden dat Nederland op dit moment een tot anderhalf miljoen mensen telt met een grote afstand tot de arbeidsmarkt die niet deelnemen aan arbeid. Op dit moment krijgen ongeveer 200.000 mensen een uitkering in het kader van de Wajong; hiervan werkt een kleine 30\%, waarvan een belangrijk deel beschut in een Sociale Werkvoorziening. 800.000 Mensen maken aanspraak op een arbeidsongeschiktheidsuitkering in het kader van de WIA, WGA of IVA. Ruim 300.000 mensen hebben een bijstandsuitkering. Daarnaast zijn er mensen die beperkt zijn en vanwege andere factoren niet onder een uitkeringsregeling vallen. Bij al deze groepen is sprake van een grote afstand tot de arbeidsmarkt, veelal ten gevolge van een beperking.

Belangrijk is het om op te merken dat de bevordering van de arbeidsparticipatie niet alleen vanuit economische motieven plaats heeft. Bekend is dat een hogere maatschappelijke participatie en deelname aan arbeid leidt tot een betere kwaliteit van leven voor diegenen die gaan participeren en tot een betere gezondheid. (Dame Black, 2008). Er is voldoende evidentie dat het participeren aan arbeid, ook als er sprake is van gezondheidsklachten of een specifieke aandoening, leidt tot een vergroting van het fysiek en psychisch welbevinden. Ook klassieke studies laten zien dat arbeid meer functies heeft dan het genereren van inkomen. Arbeid structureert de tijd, levert sociale contacten op, geeft een eigen identiteit en sociale status en vergroot de vaardigheden (Jahoda, 1982). 
Daarnaast is er een maatschappelijke druk, onder meer vanuit gehandicaptenorganisaties, gericht op het voorkomen van discriminatie vanmensen meteen beperking opbelangrijke maatschappelijketerreinen, bijvoorbeeld door het ondersteunen van beleid gericht op het volwaardig participeren van mensen met een beperking op de arbeidsmarkt. Dit beleid gericht op non-discriminatie en gelijkberechtiging is met name vanuit patiënten- en cliëntengroepen in de Angelsaksische landen naar voren gekomen. Deze benadering komt bijvoorbeeld ook naar voren in de Americans with Disability Act die de mogelijkheid biedt aan mensen met een beperking om gelijke behandeling juridisch af te dwingen. Het beleid om te komen tot gelijkwaardige behandeling heeft ook mede geleid tot een aantal belangrijke internationale verdragen: de UN-conventie met betrekking tot de rechten van mensen met een beperking (2008) en het Lissabon verdrag van de EU (2007) die de nationale overheden 'dwingt' om onder meer een gelijkwaardige arbeidspositie te creëren voor mensen met en zonder beperkingen, zijn daar een uitdrukking van. De uitsluiting van mensen met beperkingen van de arbeidsmarkt wordt maatschappelijk gezien dan ook niet meer geaccepteerd. In Nederland is in lijn met dit soort ontwikkelingen ook in de sociale zekerheidswetgeving in de afgelopen jaren meer nadruk gelegd op participatie, resulterend in een samenhang tussen het recht op een uitkering en de plicht om te werken naar vermogen.

De wetgeving op dit terrein verschilt in de verschillende Europese landen. In sommige landen, zoals Nederland, wordt gekozen voor een benadering waarin een beperking als zodanig geen reden mag zijn voor een aparte behandeling. In andere landen, waaronder Denemarken en het Verenigd Koninkrijk, wordt meer nadruk gelegd op het creëren van gelijke kansen en mogelijkheden. Dit betekent soms juist een aparte behandeling, omdat mensen met en beperking een ander startpunt hebben. Werknemers met beperkingen hebben bijvoorbeeld voorrang bij banen in de publieke sector en kunnen gebruik maken van het recht uitgenodigd te worden op een sollicitatiegesprek. Onderzoek naar de effectiviteit van dit instrument ontbreekt overigens nog (Borghouts et al, 2008).

Het waarmaken van gelijke behandeling, van een non-discriminatie waardoor eenieder met zijn beperkingen zijn mogelijkheden kan waarmaken, kan echter slechts onder de conditie dat de arbeidsmarkt voldoende in staat is om mensen met een beperking een volwaardige plek te bieden. 
Dit brengt ons dan ook naar het tweede belangrijke aspect op macroniveau, namelijk de ontwikkelingen op de arbeidsmarkt.

\section{Ontwikkelingen op de arbeidsmarkt}

Door de huidige demografische ontwikkelingen ontstaan de komende jaren tekorten op de arbeidsmarkt. Op de eerste plaats krimpt de Nederlandse beroepsbevolking vanaf 2010. In de afgelopen zestig jaar is de beroepsbevolking - iedereen tussen de 20 en de 64 jaar - gegroeid van ruim 5 miljoen naar 10 miljoen mensen. Aan deze groei is recent een einde gekomen. Door de daling in het geboortecijfer is er sprake van een dalende instroom van jongeren op de arbeidsmarkt.

Op de tweede plaats gaat de komende jaren een stijgend aantal oudere werknemers met pensioen. Deze twee ontwikkelingen leiden tot een dalend aantal mensen dat daadwerkelijk kan participeren op de arbeidsmarkt. Hierdoor komen er tot 20202.6 miljoen banen vrij, waartegenover ongeveer 2 miljoen schoolverlaters staan. Daarnaast blijft ook de vraag naar arbeid groeien. Dit betekent dat we de komende jaren met een steeds krappere arbeidsmarkt te maken hebben. Deze tekorten aan arbeidskrachten gelden voor bijna alle sectoren, maar met name in de zorg zal dit tekort nijpend worden (Commissie Arbeidsparticipatie, 2008). Er zal daardoor een structureel tekort aan arbeidskrachten gaan ontstaan. Er is dus ook een maatschappelijke noodzaak om iedereen naar vermogen te laten participeren.

Op de derde plaats is de wijze warop de arbeidsmarkt en functies op de arbeidsmarkt zich ontwikkeld hebben, een belemmerende factor geworden voor mensen met een beperking om daadwerkelijk te participeren aan arbeid. Naast de reeds beschreven kwantitatieve spanning op de arbeidsmarkt is er ook sprake van een kwalitatieve spanning en wel een groeiende afstand tussen de mogelijkheden van de persoon met zijn beperkingen en de eisen die de arbeidsmarkt stelt. Maatschappelijke ontwikkelingen, zoals automatisering en de versterking van de kenniseconomie, hebben er toe geleid dat functies complexer zijn geworden en veel elementaire werkzaamheden deel uit zijn gaan maken van meer complexe functies waardoor de arbeidsparticipatie steeds meer voorbehouden is aan een beperkte groep mensen, die hoogproductief zijn. Het gevolg hiervan is dat een deel van de samenleving niet goed meer in staat is om te participeren aan de arbeid. 
Ook de wijze waarop in de samenleving gedacht wordt over de eisen waaraan arbeid moet voldoen, evolueert op eenzelfde wijze. Zo ontwikkelen functies zich ook op basis van normatieve opvattingen over hoe een functie er uit zou moeten zien om te kunnen beantwoorden aan de eisen zoals deze anno 2011 gesteld mogen worden. In deze normatieve opvatting over arbeid staat de kwaliteit van het werk centraal, waarbij de werknemer voldoende autonomie krijgt om de werkprocessen te beïnvloeden en functies gekenmerkt worden door een veelheid aan taken van voorbereiding tot en met controle. Ook het onderzoek naar de relatie tussen Arbeid en Gezondheid laat zien dat 'gezonde' functies veelal gekenmerkt worden door variatie, flexibiliteit, controle, autonomie en verantwoordelijkheid: functies die niet passend zijn bij de mogelijkheden van veel mensen met een beperking bij wie de mogelijkheden om een volwaardige functie uit te oefenen beperkt worden door de beperking. Dit type onderzoek gaat bovendien uit van diegenen die participeren op de arbeidsmarkt en houdt geen rekening met het feit dat een deel van de bevolking door de structuur van de arbeidsmarkt niet in de gelegenheid is om te participeren. Het doet daarmee geen recht aan de diversiteit binnen de bevolking.

\section{Het realiseren van arbeidsparticipatie}

Deze processen op macroniveau hebben invloed op de wijze waarop arbeidsparticipatie in de praktijk gestalte krijgt. Om daadwerkelijk het arbeidsvermogen van mensen met een beperking te realiseren is het noodzakelijk dat werkgevers mensen met een beperking aannemen. En dat kan slechts indien er een situatie gecreëerd wordt waarbij er een positieve bijdrage is van het aannemen van mensen met een beperking op het bedrijfsproces als geheel. In dat geval:

- moeten functies beschikbaar zijn voor mensen met een beperking;

- dient een match te bestaan tussen de mogelijkheden van de individuele werknemer met zijn beperkingen en de eisen die vanuit de functie gesteld worden;

- moet, indien nodig, de ondersteuning aan de werkgever en werknemer worden geborgd om de persoon in staat te stellen om de betreffende functie ook daadwerkelijk duurzaam te kunnen verrichten.

Ergo, op het niveau van werkgever en werknemer zijn eveneens drie processen van belang die van invloed zijn op het realiseren van arbeidsparticipatie. 


\section{Het aannemen van mensen met een beperking}

In dit aanname proces speelt zowel de werkgever als de werknemer een centrale rol. Vaak wordt verondersteld dat de werkgever niet bereid is om mensen met een beperking aan te nemen. Wetenschappelijke bevindingen lijken dit niet geheel en al te bevestigen: onderzoek laat zien dat er geen eenduidig beeld is over de wijze waarop werkgevers denken over het aannemen van mensen met een beperking (van Horssen, 2010). Er zijn verschillende motieven voor werkgevers om mensen met een beperking aan te nemen. Een deel van de werkgevers laat zich door sociale motieven inspireren en vindt het vanuit het perspectief van maatschappelijk verantwoord ondernemen ook noodzakelijk om mensen met een beperking aan te nemen (Smit, 2009, Wissink et al , 2009). Internationaal vergelijkend onderzoek in vijftien Europese landen laat ook zien dat een deel van de werkgevers affiniteit heeft met de doelgroep en zich verantwoordelijk voelt om ook leden van kwetsbare doelgroepen aan te nemen. Veelal komt dit ook tot uitdrukking in een beleid gericht op maatschappelijk ondernemen of diversiteit. Organisaties die een dergelijk beleid vertaald hebben in hun bedrijfspolicies nemen vaker iemand met een beperking aan (van Lierop et al, 2007). Ook positieve ervaringen in het verleden met werknemers met beperkingen en het verstrekken van subsidies waardoor mensen met een beperking relatief goedkope arbeidskrachten zijn, kan werkgevers motiveren om mensen met een beperking aan te nemen (Siegert et al 2009, Wissink et al, 2009).

Ofschoon enkele onderzoeken laten zien dat werkgevers een positieve houding hebben om mensen met een beperking aan te nemen betekent dat nog niet dat deze positieve attitude zich onmiddellijk vertaalt in daadwerkelijk hogere aantallen mensen met een beperking die worden aangenomen. De attitude ten opzichte van een specifiek persoon met zijn beperking verschilt namelijk van de attitude ten opzichte van mensen met een beperking in het algemeen (Hernandez et al, 2000; Bruyère et al, 2003; Copeland, 2007). De beeldvorming over specifieke werknemers met een arbeidshandicap is minder positief. In een experiment van Bricout en Bentley (2000), waarbij werkgevers fictieve gekwalificeerde kandidaten moesten beoordelen, schatten werkgevers de inzetbaarheid van mensen met een beperking lager in. Daarbij werd de inzetbaarheid van werknemers met fysieke beperkingen hoger ingeschat dan die van werknemers met psychische beperkingen.

Ook in de praktijk blijkt de aard van de beperking van invloed te zijn op het aannameproces. Werkgevers blijken eerder bereid te zijn om 
mensen met een fysieke beperking aan te nemen dan om mensen met een psychische beperking aan te nemen (Commissie Werkend Perspectief, 2006). Deze negatieve beeldvorming bestaat eveneens bij leidinggevende en werknemers; zij zijn van mening dat mensen met psychische klachten vaker verzuimen en minder productief zijn (van Petersen et al, 2004). Met name het veronderstelde risico dat gepaard kan gaan met het aannemen van een werknemer met beperkingen, blijkt een belangrijke reden te zijn voor het al dan niet aannemen van mensen met een beperking. Angst voor hogere personeels- en begeleidingskosten blijkt een reden te zijn om terughoudend te zijn bij het aannemen van mensen met beperkingen. Zelfs in bedrijven die uit ervaring weten dat het met de kosten mee blijkt te vallen, blijft de angst voor hoge kosten bij het management vaak bestaan (Hernandez, 2010). Uit onderzoek in opdracht van de Commissie Werkend Perspectief blijkt dat werkgevers een verwacht hoger ziekteverzuim, lagere productiviteit en financiële risico's de belangrijkste redenen vinden om sollicitanten met een arbeidshandicap af te wijzen. Ook uit onderzoek naar plaatsing van SW'ers bij reguliere werkgevers blijkt dat dit redenen te zijn voor werkgevers om af te haken (Dijkgraaf et al, 2006). Daarnaast blijkt ook dat werkgevers de opvatting koesteren dat werknemers met een beperking onvoldoende gekwalificeerd zijn om bepaalde functies te kunnen vervullen (Fraser et al 2009).

Een andere reden die belemmerend kan zijn voor werkgevers om mensen met een beperking aan te nemen is het risico om de flexibiliteit van de organisatie te verliezen. De veranderende marktvraag dwingt organisaties tot continue aanpassingen en een hoge mate van flexibiliteit en werknemers met een beperking worden als minder flexibel en minder inzetbaar beschouwd.

De ervaring met het aannemen van mensen met een beperking door werkgevers is relatief klein (Domzal et al 2008). Deze onbekendheid met de doelgroep kan eveneens een negatieve invloed hebben op de aannamebereidheid. Bedrijven die niet bekend zijn met de Wajong regeling staan minder open om een Wajonger in dienst te nemen (van Lierop, 2008). Niet alleen het gebrek aan kennis over regelingen maar ook de onbekendheid met de doelgroep zelf en de angst 'het verkeerde' te zeggen of te doen, blijken een belemmering te zijn bij het aannemen van werknemers met een beperking (Hernandez et al, 2008). 
Bij het vergroten van de arbeidsparticipatie van mensen met een beperking zal het beleid gericht moeten zijn op het vergroten van een actieve betrokkenheid van de werkgever. Het aannemen van mensen met een beperking wordt door werkgevers gezien als risicovoller dan het aannemen van werknemers zonder beperkingen. Vandaar dan ook dat de werkgever ondersteuning moet krijgen om een medewerker met beperkingen aan te nemen zonder grote risico's. Omdat het aannemen van mensen met een beperking slechts aantrekkelijk kan zijn voor een werkgever als dit leidt tot een gelijk blijven dan wel een verbetering van het bedrijfsresultaat, moet de werkgever als het ware verleid worden tot het aannemen van mensen met een beperking. Dit moet dan ook een van de uitgangspunten zijn bij het ineenschuiven van de verschillende regelingen aan de onderkant van de arbeidsmarkt. Diverse pilots onder werkgevers leren dat werkgevers wel bereid zijn om mensen met een beperking op te nemen, maar dat zij huiverig zijn om ze blijvend aan te stellen. Een van de daarbij genoemde argumenten is dat de huidige ondersteuning goed geregeld is, maar dat onduidelijk is of dat ook in de toekomst zo zal blijven (Mallee et al, 2010). De overheid wordt daarbij als een onbetrouwbare partner afgeschilderd die bestaande regelingen kan intrekken en daarmee de werkgever op kosten kan jagen.

Het waarborgen van een goede begeleiding en ondersteuning van werkgever en werknemer, het realiseren van proefperiodes en het voorkomen dat de werkgever geconfronteerd wordt met onverwachte negatieve risico's, vergroten de aannamebereidheid evenals een positieve draagvlak onder het personeel en betrokkenheid van het management (van Lierop, 2007; Borghouts et al, 2008; Siegert et al, 2009). Onverwachte negatieve risico's kunnen opgevangen worden indien er een duurzame relatie ontstaat tussen de werkgever en een dienstverlener (re-integratiebedrijf, SW-bedrijf) die in staat is om vanuit het bedrijfsbelang met de werkgever mee te denken (Graffman et al, 2002). Dienstverleners die goed op de hoogte zijn van de vraag van de werkgever, het werkproces en de beschikbare mogelijkheden kennen, zijn beter in staat passende kandidaten aan te dragen (Corden en Thornton, 1997).

Zoals eerder gesteld moeten organisaties flexibel op ontwikkelingen in de markt kunnen reageren. Het aannemen van werknemers met een beperking kan volgens werkgevers deze flexibiliteit negatief beïnvloeden, ook dit maakt werkgevers huiverig om mensen met een beperking aan te nemen. Dit impliceert dat bij beleidsontwikkeling gericht op het vergroten van de arbeidsparticipatie van mensen met een beperking, 
voorwaarden gecreëerd worden om werkgevers te ondersteunen mensen met een beperking in dienst te nemen zonder dat de flexibiliteit van de organisatie verminderd wordt. Een mogelijkheid daartoe is een detacheringsconstructie, zoals deze onder meer door uitzendbureaus, maar ook door SW bedrijven gehanteerd wordt bij het plaatsen van medewerkers met een beperking in een reguliere arbeidssetting. Op deze wijze kunnen ook werknemers worden ondersteund bij de overgang van de ene naar een andere functie.

\section{De werknemer aan de onderkant van de arbeidsmarkt}

Eerder is al aangegeven dat de aandacht in deze rede vooral uitgaat naar het vergroten van het werkvermogen van die mensen die zonder ondersteuning niet in staat zijn om op de reguliere arbeidsmarkt het minimuminkomen te verdienen. Op basis van bestaand onderzoek is bekend (Holwerda et al, 2010) dat het een zeer gemêleerde groep betreft met zeer uiteenlopende arbeidsmogelijkheden. Hun gemeenschappelijk kenmerk is het feit dat zij extra ondersteuning nodig hebben om hun arbeidsmogelijkheden waar te maken en dat zij zonder die ondersteuning niet in staat zijn om het minimumloon te verdienen op de reguliere arbeidsmarkt. Dit impliceert dat er, afhankelijk van de individuele kenmerken van de persoon, verschillende problemen zijn met betrekking tot de aansluiting op de arbeidsmarkt en de ondersteuning die daarbij nodig is.

Onderzoek (Groothoff et al, 2008) laat zien dat er weinig tot geen evidence based technieken zijn om mensen met een grote afstand tot de arbeidsmarkt gericht te ondersteunen en te motiveren richting arbeid. Evenmin zijn de bestaande assessmentinstrumenten gericht op het bepalen van de arbeidsgerelateerde mogelijkheden van een werknemer met beperkingen. Integendeel, het merendeel van de bestaande assessment methodieken lijkt vooral inzicht te bieden in de beperkingen van iemand en niet in de wijze waarop hij met de aanwezige beperkingen zijn resterende mogelijkheden kan benutten.

\section{Ontwikkeling in beschikbare functies}

Een voorwaarde voor de vergroting van de arbeidsparticipatie van mensen met een beperking is dat er voldoende geschikte functies beschikbaar zijn, dat een arbeidsmarkt gerealiseerd wordt die open staat voor mensen met beperkingen en met een (blijvende) ondersteuningsbehoefte. Uitgangspunt is dat de wijze waarop functies zich ontwikkeld hebben zowel bevorderend als belemmerend kunnen werken op het realiseren 
van de arbeidsmogelijkheden van mensen met een beperking. Om een beeld te schetsen van de wijze waarop functies op de arbeidsmarkt zich ontwikkeld hebben onder invloed van mechanisering en automatisering zal ik een korte schets geven van de ontwikkeling van functies in de afgelopen honderd jaar en de consequenties van deze ontwikkeling voor de arbeidsmogelijkheden van mensen met een beperking (zie voor een uitvoerige beschrijving: Zijlstra et al, 2011).

Zoals in het begin al is gememoreerd, is het exact honderd jaar geleden dat Taylor (1911) de grondslag legde voor een verregaande functiedeling. Als civiel ingenieur in de Bethlehem Steel Works voerde hij 'tijd en bewegingsstudies' uit - die nu bekend staan als arbeidsanalyse - waarmee hij mat hoe lang bepaalde arbeidshandelingen en werkprocessen duurden, en bedacht vervolgens of en hoe het ook sneller kon waardoor ook de efficiency van het productieproces vergroot kon worden (Scientific Management). In essentie kwam het er op neer dat Taylor een onderscheid aanbracht tussen mensen die het werk plannen en bedenken hoe het uitgevoerd moet worden ('hoofdarbeid') en mensen die het werk uitvoeren ('handarbeid'). Hierdoor ontstonden verschillende functies op verschillende niveaus die ook door werknemers met verschillende capaciteiten uitgevoerd konden worden. Een schaduwzijde was dat, door de strikte toepassing van de scheiding van hoofd- en handarbeid, het 'uitvoerende' productiewerk vaak erg eenvoudig en simpel werd. Met name omdat na de invoering van de lopende band het aantal eenvoudige functies sterk toe nam, werd het in de praktijk steeds moeilijker om werknemers te motiveren om deze eenvoudige productietaken te verrichten. Veel van het werk werd als 'geestdodend' en monotoon gekarakteriseerd.

Het feit dat het Scientific Management van Taylor tot monotone arbeid en tot ontscholing leidt en negatieve gedragseffecten met zich meebrengt, vormt de aanleiding voor de ontwikkeling van activiteiten gericht op het vergroten van de kwaliteit van de arbeid, enerzijds vanuit het aspect van 'taakontwerp' (job design) en anderzijds vanuit het herontwerp van werkprocessen (socio-techniek). Uitgangspunt van taakontwerp is om de arbeid zodanig vorm te geven dat het welzijn en ook de productie van de werknemer wordt bevorderd. Hierbij vormt de motivatie van mensen om het werk te doen in eerste aanleg een belangrijk uitgangspunt (vgl. Hackman \& Oldham, 1976). Naderhand komt daar ook het punt van persoonlijke ontwikkeling van werknemers bij. Door middel van taakroulatie, en later van taakverrijking (horizontaal 
en ook verticaal), werd geprobeerd om het werk aantrekkelijker en interessanter voor werknemers te maken.

De ontwikkeling van technologie, van mechanisering tot automatisering, is er op gericht om activiteiten van mensen door machines te laten overnemen en daardoor een grotere beheersing van kosten en zekerheid van de productie te realiseren (Zijlstra, Schalk en Roe, 1996; Zijlstra, 2003). Omdat de technologische ontwikkeling in eerste instantie nog beperkt was, zijn nog steeds mensen nodig voor het productieproces. De coördinatie van de diverse activiteiten, waarbij vooral 'de onderlinge timing van activiteiten' en 'positionering van producten in de machines' belangrijke elementen zijn, moet nog door mensen gebeuren. Het inzicht dat productietechnologie en de organisatie van het werk sterk met elkaar samenhangen wordt vooral opgepakt door mensen van het Tavistock Institute. Met name Emery (1959) presenteerde het socio-technisch systeem denken. Het socio-technisch systeem denken is gebaseerd op de uitgangspunten van 'participatief taakontwerp', een destijds moderne manier van Organisatie Ontwikkeling. Het uitgangspunt van deze stroming is dat 'technische systemen' (de machines) en 'sociale systemen' (de mensen, organisatie) in wederzijdse afhankelijkheid moeten worden ontworpen en dat er gestreefd moet worden naar 'joint optimization'. Dat houdt in dat bij het ontwerpen van technologische systemen rekening gehouden moet worden met de beperkingen en mogelijkheden van mensen en dat de wijze waarop het werk georganiseerd werd, hier een weerslag van moest zijn.

Vanuit deze socio-technische benadering verschuift het accent van individuele taakontwerpen naar taakontwerp op groepsniveau. In de productieorganisatie wordt uitgegaan van groepsgewijze productie, waarbij groepen werknemers (teams), tot op zekere hoogte, zelf de onderlinge afstemming kunnen bepalen. Dat heeft, vooral in Nederland, er toe geleid dat in de jaren tachtig en negentig veel organisaties hun productieprocessen zijn gaan baseren op teams. Er wordt onderscheid gemaakt in teams afhankelijk van hoeveel invloed de individuele groepsleden hebben op de organisatie van het werk. Zo wordt onderscheid gemaakt tussen semi-autonome teams en autonome teams, afhankelijk. Bij volledig autonome teams wordt de organisatie en onderlinge afstemming van het werk geheel aan de teamleden overgelaten. Dit stelt hoge eisen aan de werknemers: naast vakmatige kennis en vaardigheden, dienen ze ook organisatorische en vooral ook sociale vaardigheden te hebben om met collega's te kunnen 'onderhandelen' over de werkverdeling. 
Deze verschuiving van individuele functies naar werken in groepen wordt nog versterkt door een andere ontwikkeling: een groeiende flexibilisering in de arbeidsprocessen. Zowel in de dienstensector als in de hoogwaardige maakindustrie kan een groeiende noodzaak geconstateerd worden om producten en diensten te leveren die aansluiten bij de individuele vraag van de klant. Dit betekent dat standaardisering van producten en diensten niet langer het uitgangspunt is, maar dat men zo snel mogelijk in moet spelen op de vraag van de markt. De organisatorische oplossing hiervoor is om teams verantwoordelijk te maken voor bepaalde delen van het proces. Door middel van teams is men beter in staat om te reageren op wisselingen in de vraag. Teams kunnen zichzelf organiseren en reguleren en kunnen daardoor flexibel opereren en problemen oplossen. Het organiseren van processen in teams stelt hogere eisen aan werknemers; zij moeten in teams kunnen werken, flexibel ingezet kunnen worden en zij moeten allround zijn omdat ze elk moment binnen het team voor elkaar in moeten kunnen vallen. Daarnaast zijn ook door de vergroting van de dienstensector andere competenties noodzakelijk om goed te kunnen functioneren. Met name kan daarbij gedacht worden aan communicatieve vaardigheden, bijvoorbeeld om te kunnen omgaan met de vraag van de klant.

\section{Betekenis van functies voor de eisen die aan werknemers gesteld worden}

De hierboven geschetste ontwikkeling laat zien dat de organisatie van de productie in de loop der tijd verandert en dat deze veranderingen gevolgen hebben voor de eisen, kennis, vaardigheden ('competenties'), die aan werknemers worden gesteld. Er is dus een samenhang tussen de wijze waarop het werk is georganiseerd en de eisen die dat met zich meebrengt voor de mensen die het werk moeten doen. Door deze ontwikkelingen is om drie redenen de toegang tot de arbeidsmarkt voor mensen met een beperking afgenomen.

Op de eerste plaats hebben bovengenoemde ontwikkelingen in de arbeidsmarkt geleid tot een uitstoot van simpel werk. In veel arbeidsorganisaties zijn functies in elkaar geschoven. Daarbij zijn afzonderlijke voorbereidende, uitvoerende en controlerende taken in één functie verenigd; taken die voorheen deel uitmaakten van verschillende meer complexe én meer elementaire functies. Deze ontwikkeling wordt ondersteund door het denken in termen van kwaliteit van de arbeid, op basis waarvan functies volwaardig dienen te zijn en functies gekenmerkt worden door een hoge mate van controle door de werknemer, vanuit de kennis dat voor het merendeel van de werknemers een meervoudige 
taak tot een groter werkplezier en tot meer welzijn in de arbeid zal leiden.

Op de tweede plaats is arbeid in de afgelopen decennia steeds meer georganiseerd in homogene teams, waarbij medewerkers uitwisselbaar moeten zijn en dus over allround vaardigheden moeten beschikken. Dit eist een flexibele inzet van medewerkers waarbij mensen elkaar onderling kunnen vervangen en over een breed scala van deskundigheden moeten beschikken. Deelname aan het moderne arbeidsproces stelt dan ook steeds hogere eisen aan cognitief en sociaal functioneren.

Op de derde plaats is de arbeidsmarkt steeds meer ingericht om snel te kunnen reageren op wijzigingen in de vraag. Met name voor een aantal, meer eenvoudige, functies heeft dit geleid tot een toename aan flexibele en tijdelijke arbeidscontracten die niet gericht zijn op duurzame arbeidsparticipatie. Tegelijkertijd heeft de stijging van de productiviteit en verandering van de functie-inhoud er toe geleid dat functies die in het verleden als elementair werden gezien dit nu niet meer zijn. Gedacht kan daarbij worden aan bijvoorbeeld functies binnen de schoonmaak, die nu gekenmerkt worden door functie-eisen als snelheid, machinegebruik, de grote hoeveelheid schoonmaakmiddelen en dergelijke. De functie-eisen zijn dermate aangescherpt dat deze schoonmaakfuncties zelfs voor veel mensen met een beperking aan de onderkant van de arbeidsmarkt onbereikbaar zijn geworden. De veranderingen in de arbeid, een groter beroep op kennis en vaardigheden hebben dus tot een segregatie op de arbeidsmarkt geleid tussen diegenen die aan de moderne productieeisen kunnen beantwoorden en diegenen die dat niet kunnen.

Deze bevinding, dat het aantal functies voor mensen met beperkingen gedaald is, lijkt in tegenstelling tot onderzoek van het SCP (Josten, 2010) waarin wordt geconstateerd dat het aantal banen aan de onderkant van de arbeidsmarkt niet substantieel gedaald is. Mijns inziens klopt de redenering vanuit het SCP dan ook niet en is het rapport intern niet consistent in haar bevindingen. Het SCP geeft in zijn publicatie aan dat het aantal functies aan de onderkant van de arbeidsmarkt voor mannen substantieel is afgenomen, terwijl het aantal elementaire functies voor vrouwen is toegenomen; in het bijzonder in de schoonmaak. Dit impliceert dat de kans op elementaire functies aan de onderkant van de arbeidsmarkt voor mannen is afgenomen, tegelijkertijd blijkt de inhoud van dergelijke elementaire functies in de praktijk in een groot aantal gevallen aanmerkelijk veranderd te zijn. De functiebenaming is nog wel hetzelfde gebleven, maar de daadwerkelijke inhoud van de functie of de omstandigheden (bijvoorbeeld tijdsdruk) waaronder die 
functie uitgevoerd moet worden, stelt andere eisen. Daarnaast wordt door het SCP geconstateerd dat veel van deze functies in tijdelijke of flexibele contracten is georganiseerd. Dit betekent dat deze functies veelal worden ingenomen door mensen die gemakkelijk in een dergelijke functie kunnen werken (scholieren, bijverdiensten), maar in mindere mate geschikt zijn als een duurzame arbeidsrelatie. Beide elementen, een verandering van de arbeidsinhoud en -voorwaarden, zijn een beletsel voor veel mensen met een beperking om duurzaam toe te treden tot de arbeidsmarkt. Op dit punt kom ik later nog terug.

Uit voorgaande wordt duidelijk dat de eisen die aan mensen worden gesteld het directe gevolg zijn van de wijze waarop (productie)processen in de loop der tijd zijn georganiseerd. De wijze van organiseren en produceren is voortdurend aan veranderingen onderhevig. Vaak is de drijfveer een technologische verandering, soms een organisatieverandering vanwege veranderingen in de markt (consumentenvraag). Veelal zijn veranderingen in functie een afgeleide van technologische of kennisontwikkelingen. Dergelijke veranderingen vinden plaats op organisatieniveau en wordt er maar in beperkte mate rekening gehouden met de betekenis van deze ontwikkelingen voor de arbeidsmarkt. Indien de samenleving constateert dat er een misfit ontstaan is tussen de ontwikkeling in functies en de mogelijkheden van de arbeidsmarkt, leidend tot een verminderde participatie van specifieke groepen, dan moet dat tot een beleid leiden gericht op her-creëren van functies om de gevraagde functie-eisen in overeenstemming te brengen met de kwaliteiten en mogelijkheden van het beschikbare arbeidsaanbod.

\section{De mogelijkheden van de werknemer}

Om mensen met een grote achterstand te kunnen plaatsen op de arbeidsmarkt is het primair noodzakelijk om de competenties en ontwikkelingsmogelijkheden van deze groep te bepalen. Dit is niet altijd even simpel omdat veel assessment instrumentarium gericht is op het bepalen van de beperkingen en de onmogelijkheden en niet op de resterende of te ontwikkelen capaciteiten. Om te komen tot een goede match tussen de persoon en de eisen die de functie stelt is het noodzakelijk om betrouwbare uitspraken te kunnen doen over de specifieke arbeidsmogelijkheden.

Deze assessment is des te complexer omdat niet alleen de geconstateerde beperking een rol speelt, maar in een groot aantal 
gevallen is er ook nog sprake van secundaire beperkingen die de weg naar arbeid compliceren. Secundaire beperkingen zijn beperkingen die niet direct causaal gerelateerd zijn aan de beperking, maar daar wel mee samen kunnen hangen en in ieder geval het vergroten van de arbeidsparticipatiemogelijkheden in de weg staan. Daarbij moet gedacht worden aan verschillende aspecten zoals onder meer: een schuldenproblematiek, een negatief zelfbeeld, gevoelens van onvermogen vanwege eerdere faalervaringen, een overbeschermende omgeving en/of het niet geaccepteerd hebben van de eigen aandoening of beperking. Het gaat hierbij vooral om de psychische impact van de bestaande problemen, die een verder handelen richting duurzame arbeidsdeelname belemmeren.

Onderzoek van van Hal et al (2009) laat zien dat een deel van deze werknemers door deze secundaire belemmeringen niet in staat is om zelf regie te voeren over hun re-integratiebeleid. De gangbare benadering bij re-integratie om mensen aan te spreken op de eigen verantwoordelijkheid werkt bij deze groep niet. Op basis van iemands beperkingen en mogelijkheden, zoals deze vastgesteld zijn bij de assessment, moet dus eveneens vastgesteld worden welke ondersteuning de betreffende werknemer nodig heeft om optimaal te kunnen functioneren in de werksituatie. Het is onmogelijk, net zo goed als in een regulier selectieproces om alle risico's op een onvoldoende match tussen de mogelijkheden van de werknemer en de eisen die het werk stelt, uit te sluiten. Alleen bij mensen met een beperking wordt door werkgevers dit risico als groter beschouwd dan in het geval van een niet beperkte werkgever. Er zijn een aantal mogelijkheden om het risico voor de werkgever te verminderen of uit te sluiten. Een van de meest gehanteerde vormen is de detacheringsconstructie. Hierbij komen de risico's van een aanname van een werknemer met beperkingen niet bij de werkgever te liggen en is er altijd een terugval optie voor de werknemer met beperkingen als hij niet aan de eisen van de functie kan beantwoorden. Een dergelijke detachering beschermt dus zowel de werknemer als de werkgever en legt de basis voor een duurzame arbeidsrelatie.

\section{Naar een toekomstgerichte benadering}

We hebben geconstateerd dat de non-participatie van mensen met een beperking voor een deel verklaard moet worden uit een mismatch tussen de kwaliteiten en de mogelijkheden van mensen met een grote afstand tot de arbeidsmarkt en de inhoud van de beschikbare functies. 
Het vergroten van de arbeidsparticipatie vraagt dan ook tegelijkertijd om het benutten van de arbeidsmogelijkheden van mensen met een beperking en om een verandering binnen de bestaande functiestructuur om een match te creëren tussen de mogelijkheden van de werknemer met beperkingen en de eisen die een functie stelt. Het realiseren van het werken naar vermogen door mensen met een beperking vraagt daarom tegelijkertijd dat de samenleving het vermogen om te werken realiseert. Daarbij blijkt dat de bestaande functie-opbouw en functieinhoud geen goed uitgangspunt te zijn bij het streven naar een zo groot mogelijke participatie van mensen met een beperking. Vandaar dat bij de transformatie van de arbeidsmarkt naar het meer inclusief maken van de arbeidsmarkt en de arbeidsorganisatie, niet uitgegaan moet worden van de functies zoals deze zich ontwikkeld hebben in de afgelopen jaren maar moet worden uitgegaan van de basis van deze functies; van de werkzaamheden zoals deze verricht moeten worden om tot het uiteindelijke productieresultaat te komen. Op basis van deze werkzaamheden kunnen opnieuw functies gecreëerd worden, bestaande uit een andere set van werkzaamheden die passen bij de mogelijkheden van de persoon met beperkingen. Om dit te kunnen doen blijken, honderd jaar na Taylor opnieuw Tayloriaanse arbeidsanalyses noodzakelijk om functies te ontleden en op basis van de bestaande werkzaamheden te komen tot nieuwe, vaak elementaire functies. Op macroniveau zal een herstructurering van de arbeidsmarkt een noodzakelijke voorwaarde zijn om de maatschappelijke doelstelling van vergroting van de participatie van mensen met een grote afstand tot de arbeidsmarkt te realiseren. Op organisatieniveau moeten werkgevers ondersteund worden om een nieuwe functiestructuur te ontwikkelen die recht doet aan de vraag naar personeel en aan de bedrijfskundige eisen en tegelijkertijd aan de mogelijkheden van de mensen op de arbeidsmarkt.

\section{Het creëren van een inclusieve arbeidsmarkt}

Participatiebevordering aan de onderkant van de arbeidsmarkt vraagt daarom zowel iets van de persoon met zijn beperkingen als van de arbeidsmarkt. Voor de persoon met zijn beperkingen betekent dit dat hij zijn eigen arbeidsvermogen waar moet maken en dat hij daarin zo nodig ondersteund moet worden en tegelijkertijd moeten er op de arbeidsmarkt voldoende geschikte functies zijn om dit arbeidsvermogen ook daadwerkelijk te realiseren.

De huidige arbeidsmarkt is, gelet op de bestaande functies en op de 
eisen die de bestaande werkomgeving aan de werknemer stelt, niet in staat om op ruime schaal mensen met een grote afstand tot de arbeidsmarkt op te nemen. Functies zijn daarvoor te complex geworden, vragen een te hoge handelingssnelheid, een grote flexibiliteit en doen veelal een te groot beroep op sociale vaardigheden. Om de participatie van mensen met een grote afstand tot de arbeidsmarkt daadwerkelijk te vergroten en bovendien een vorm van duurzame arbeidsparticipatie te realiseren moeten nieuwe functies gecreëerd worden die wél matchen met de mogelijkheden van deze groep werkzoekenden.

In de afgelopen jaren is een aantal verschillende methodieken ontwikkeld om nieuwe functies te creëren, methodieken die vaak toegesneden zijn op specifiek doelgroepen, maar in hun benadering sterk overeenkomen. Ik zal een tweetal methodieken kort de revue laten passeren. De eerste benadering, die al langer bestaat, is de methodiek van Job Carving; veel andere gehanteerde methodieken maken gebruik van elementen van de job carving methodiek. De tweede methodiek is recent ontwikkeld door onderzoekers vanuit de vakgroep Arbeids- en Sociale Psychologie in samenwerking met UWV.

\section{Job Carving}

Bij job carving wordt primair uitgegaan van het proces van het matchen van de mogelijkheden van de werknemer en het creëren van een specifieke functie. Deze methodiek wordt vaak toegepast bij het detacheren van medewerkers vanuit bijvoorbeeld de Sociale Werkvoorziening naar functies op de reguliere arbeidsmarkt. Bij reguliere werkgevers wordt gekeken welke werkzaamheden blijven liggen, bijvoorbeeld ten gevolge van een hoge werkdruk bij de aanwezige werknemers, en van deze werkzaamheden wordt een nieuwe functie gecreëerd die uitgevoerd kan worden door een medewerker met zijn beperkingen. Bij de bepaling van welke werkzaamheden geschikt kunnen zijn voor een functie voor een medewerker, wordt uitgegaan van de mogelijkheden van de betreffende persoon aanwezig. Dit vraagt om een concreet werkprofiel van de persoon waarin beschreven staat welke werkzaamheden hij kan uitvoeren, onder welke condities en welke ondersteuning eventueel geboden moet worden door de dienstverlener. Nadat vastgesteld is dat er binnen een reguliere organisatie mogelijk werkzaamheden ingevuld kunnen worden door een medewerker met beperkingen, wordt gekeken of de mogelijkheden van de betreffende medewerker matchen met de eisen die de geselecteerde werkzaamheden vragen. Deze methodiek 
koppelt de individuele mogelijkheden, vaardigheden, interesses en ondersteuningsbehoefte aan een functie en een werkomgeving. Job carving is daarmee ook een geïndividualiseerde aanpak. Een functie wordt gecreëerd door het afs plitsen van bepaaldeeenvoudige functieonderdelen van bestaande functies. Redenen voor deze afsplitsing is veelal dat de werkdruk bij het zittende personeel te hoog is waardoor zij onvoldoende toekomen aan hun specifieke taken of werkzaamheden blijven liggen door de hoge werkdruk. In een aantal gevallen kan het ook zijn omdat eenvoudige werkzaamheden teveel tijd vergen waardoor de geschoolde werknemer onvoldoende toekomt aan de meer complexe handelingen. Het betreffen dan meestal ondersteunende werkzaamheden, die goed uitgevoerd kunnen worden door een werknemer met beperkingen. Deze eenvoudige functieonderdelen worden dan vervolgens gecombineerd tot een nieuwe functie en wel op een zodanige wijze dat de kwaliteit en productiviteit van de organisatie vergroot wordt (Nietupski, 1993; Nietupski en Hamre-Nietupski, 2000; van Soest et al, 2007).

Kern in deze benadering is een goede assessment van de mogelijkheden en beperkingen van potentiële werknemer gericht op zijn concrete werkmogelijkheden en een goede beschrijving van de eisen die een functie stelt en van de werkomgeving. Ook de ondersteuning na de plaatsing is een belangrijk aspect bij de meeste beschrijvingen van job carving methodieken (Griffin, 2003, van Soest et al, 2007). Een belangrijk element in deze benadering is het ad hoc karakter: bestaande functies worden vrijwel niet beïnvloed,de nieuwe functies bestaan veelal uit werkzaamheden die in de marge van het werkproces liggen. Voor de organisatie brengt het creëren van een dergelijke eenvoudige functie met zich mee dat er economisch voordeel behaald kan worden, omdat bijvoorbeeld hoger opgeleid personeel niet gehinderd wordt door deze bijkomende werkzaamheden, waardoor deze werknemers zich meer kunnen bezighouden met de hoger gekwalificeerde taken. Hierdoor kunnen zij productiever zijn.

\section{Inclusief herontwerp van werkprocessen}

Uitgangspunt bij inclusief herontwerp is dat de functiestructuur zoals deze zich in de afgelopen decennia ontwikkeld heeft, niet overeenkomt met de kwaliteiten van potentiële werknemers op de arbeidsmarkt. Een dergelijke mismatch zal, ondanks een toenemende spanning op de arbeidsmarkt, blijvend leiden tot een hoge structurele werkloosheid onder werknemers met een beperking die, vanwege deze beperking, een grote afstand tot de arbeidsmarkt hebben. De huidige arbeidsmarkt 
is, gelet op de bestaande functies en op de eisen die de bestaande werkomgeving aan de werknemer stelt, niet in staat om op ruime schaal mensen met een grote afstand tot de arbeidsmarkt op te nemen. Functies zijn, zoals ik eerder heb laten zien, daarvoor te complex geworden. Functies op de huidige arbeidsmarkt vragen veelal een te hoge handelingssnelheid, een grote flexibiliteit en doen een groot beroep op sociale vaardigheden. Om de participatie van mensen met een grote afstand tot de arbeidsmarkt op de vereiste schaal en bovendien duurzaam te realiseren moeten nieuwe functies gecreëerd worden die wel matchen met de mogelijkheden van deze groep werkzoekenden: een jongere met verstandelijke beperkingen kan bijvoorbeeld goed functioneren op een werkplek die bestaat uit elementaire taken zonder een al te grote zelfstandigheid en verantwoordelijkheid en met adequate (bege)leiding.

Verwacht wordt dat de arbeidsmarkt de komende jaren krapper zal worden vanwege de vergrijzing en ontgroening. Tekorten op de arbeidsmarkt zijn nu al waarneembaar bij een aantal technische beroepen (procesoperators op $\mathrm{MBO}_{3} / 4$ niveau) en in de zorgsector. De bestaande organisatiestructuur van bedrijven staat echter niet toe dat de personeelstekorten, althans voor een deel, worden opgelost door een grotere participatie van mensen die nu buiten het arbeidsproces staan. Hiervoor is een innovatief herontwerp van arbeidsorganisaties noodzakelijk (Walkowiak et al, 2009). Uitgaande van een integrale bedrijfsanalyse worden in een bedrijf elementaire taken opgespoord, beschreven, en getypeerd naar relevante functie-eisen. In een vervolgfase kunnen die elementaire taken op verschillende manieren worden gecombineerd tot elementaire functies, in afstemming met bestaande functies, die hierdoor eveneens veranderingen kunnen ondergaan. De uiteindelijke vormgeving van de elementaire functies en de overige functies is afhankelijk van de mogelijkheden van individuele kandidaat-uitvoerders met hun functionele beperkingen én de eisen en mogelijkheden vanuit de bedrijfsvoering. 
Inclusief herontwerp van werkprocessen (IHW) in 9 stappen:

1. Commitment van bedrijfsleiding en personeelsvertegenwoordiging om nieuwe collega's met beperkingen te integreren in het bedrijf

2. Integrale analyse van de werkprocessen om elementaire taken op te sporen (long list), in relatie tot de bestaande taakverdeling in functies

3. Instemming van de bedrijfsleiding om verdere analyse te starten in specifieke onderdelen van het bedrijf, additionele afspraken over randvoorwaarden (kaderstelling)

4. Participatief herontwerp van werkprocessen en functies in overleg met werknemers en leidinggevende(n) van de betrokken afdelingen; valideren van de gevonden elementaire taken; ontwikkelen van ideeën voor re-allocatie van bestaande taken om nieuwe elementaire functies te creëren in samenhang met de bestaande functies: elementaire taken per afdeling (short list)

5. Werving en selectie en voorbereiding van kandidaten die over voldoende elementaire bekwaamheden beschikken om de elementaire taken (short list) uit te kunnen (leren) voeren, en die hiertoe ook gemotiveerd zijn

6. Clustering van elementaire taken tot elementaire functies die zijn afgestemd op de individuele kandidaten en op de ontvangende afdeling

7. Introductie van de kandidaten in hun nieuwe werkomgeving, managen van wederzijds verwachtingen, initiële training en begeleiding door collega (werkbegeleider), jobcoach of direct leidinggevende

8. Regelmatige feedback door werkbegeleider en leidinggevende; indien nodig opnieuw aanpassingen van de taken totdat een duurzame toestand is bereikt, re-integratie geslaagd, of re-integratie niet geslaagd: nieuwe kandidaat (terug naar stap 5)

9. Evaluatie van het project door bedrijfsleiding en vertegenwoordigers uit de betrokken afdelingen om te bepalen of en zo ja, hoe het project wordt gecontinueerd

Een nieuwe taakstructuur beïnvloedt ook de bestaande bedrijfsprocessen. Vandaar dat de randvoorwaarden voor deze vorm van taak(her) structurering vooraf op directieniveau moeten worden vastgesteld, mede op basis van de resultaten van de integrale bedrijfsanalyse. De fase van bedrijfsanalyse wordt afgesloten met een besluit van de bedrijfsleiding, waarin vastgesteld wordt of, en zo ja op welke afdelingen, in welke omvang en onder welke kaderstellende voorwaarden taak(her) 
structurering past binnen de bedrijfsvoering.

Cruciaal is in deze methodiek, dat voorstellen voor te creëren elementaire functies in nauw overleg met de werkvloer (direct leidinggevende en collega's) worden ontwikkeld. Er worden namelijk niet alleen nieuwe functies aan de onderkant van de arbeidsmarkt gecreëerd, maar het afscheiden van elementaire taken leidt ook tot veranderingen van functie-inhoud van (sommige van) de oorspronkelijke functies. Ook taakelementen die wellicht beschouwd kunnen worden als momenten van rust of afwisseling in de oorspronkelijke functies vallen mogelijk weg. Overleg met de zittende werknemers over de te ontwikkelen nieuwe werkverdeling is daarom ook belangrijk om de kwaliteit van de arbeid van alle betrokken werknemers te kunnen bewaken in het herontwerpproces.

De nieuwe werknemers op de elementaire functies zullen de toekomstige collega's worden van de zittende werknemers, wier functies ook in meer of mindere mate zullen veranderen door deze innovatie. ledereen zal elkaar moeten (leren) accepteren in de nieuwe werksituatie en sommige van de zittende werknemers zullen ook een taak krijgen in de begeleiding van de nieuwe werknemers. Het noodzakelijke draagvlak voor zo'n organisatieverandering is zeer gebaat bij de participatieve benadering in de ontwerpfase. Hiermee wordt een belangrijke fundament gelegd voor een implementatie van het ontwerp dat moet resulteren in duurzame arbeidsparticipatie van de toekomstige werknemer(s) met beperkingen.

Inclusief herontwerp van werkprocessen gaat uit van de taken en bedrijfsprocessen zoals deze op dit moment bestaan. Als gevolg van het herontwerp ontstaan er volledig nieuwe elementaire functies maar ondergaan ook bestaande functies meer of minder ingrijpende veranderingen. Sommige bestaande functies kunnen wellicht zelfs vervallen, andere functies zullen minder ondersteunende en additionele taken bevatten. Deze functies zullen worden geconcentreerd rond kerntaken, die een beroep doen op specifieke beroepskwalificaties. Uitgangspunt bij IHW is dat de kwaliteit van het product, de dienst of de zorg minimaal gelijk blijft, en liefst nog verder wordt verhoogd. Hetzelfde geldt voor kwantiteit en tijdigheid. Uitgangspunt is eveneens dat de totale personeelskosten niet toenemen, in het gunstigste geval zelfs zullen afnemen. Deze verwachting is gebaseerd op de aanname dat er organisatiebreed minder een beroep zal hoeven worden gedaan op (schaarse) gekwalificeerde vakkrachten omdat zij een aantal werkzaamheden die niet per se hun specifieke vakbekwaamheid 
vereisen, niet langer behoeven uit te voeren. Aan de inzet van laaggekwalificeerde werknemers voor de uitvoering van elementaire werkzaamheden zijn lagere loonkosten verbonden. Afhankelijk van de gerealiseerde productiviteit kan de loonwaarde van werknemers met (forse) beperkingen ook lager zijn dan het wettelijk minimumloon (WML), onder toepassing van loondispensatie. Eventuele extra kosten in de vorm van een verhoogd verzuimrisico zijn afgedekt met de zogenaamde no-riskpolis ('vangnet' Ziektewet), Evenzeer zijn er binnen de bestaande regelgeving mogelijkheden voor de financiering van de extra kosten die verbonden kunnen zijn aan de, tijdelijke of blijvende, begeleiding van deze nieuwe groep werknemers.

Met Inclusief herontwerp van werkprocessen zijn bijvoorbeeld in het Slotervaart Ziekenhuis positieve resultaten opgedaan met betrekking tot het plaatsen van jongeren met een beperking. Op een totaal personeelsbestand van 1500 werknemers worden zo'n 100 tot 150 reguliere en duurzame functies voor jongeren met een beperking gecreëerd. Ook in andere sectoren zijn positieve ervaringen opgedaan met betrekking tot functieherontwerp.

\section{Betekenis voor het onderzoeksprogramma}

De hierboven beschreven ontwikkelingen vormen de basis voor het onderzoeksprogramma zoals dat vanuit deze leerstoel vormgegeven zal worden. Onderzoek binnen de arbeids- en organisatiepsychologie is meestal gericht op generieke factoren: onderzoeksresultaten laten zien wat de belangrijkste motiverende en belastende factoren in de werksituatie zijn voor werknemers die in staat zijn om regulier te kunnen functioneren. Op basis van de in deze rede genoemde bevindingen weten we dat algemene uitspraken over factoren die de kwaliteit van de arbeid bepalen, niet onverkort geldig zijn voor werknemers aan de onderkant van de arbeidsmarkt. Onderzoek naar de factoren die het mogelijk maken voor werknemers met een beperking om te kunnen functioneren op de arbeidsmarkt en naar de wijze waarop het werk in dat geval het beste georganiseerd kan worden, vraagt om een ander onderzoeksperspectief. Niet langer staat het generieke centraal, maar juist wordt gekeken naar het specifieke. Primair zal de aandacht uitgaan naar de wijze waarop de diversiteit in het arbeidsaanbod leidt tot een diversiteit in functies en tot een optimale belasting in de werksituatie. Ik heb laten zien dat het vragen aan mensen met een beperking om te werken naar vermogen vraagt om een inrichting van de werkplek om 
het vermogen om te werken ook te realiseren. Dit zal ook de kern van het onderzoek zijn. Meer concreet betekent dit dat het onderzoek gericht zal zijn op aspecten die een rol spelen bij het vormgeven van organisaties opdat zij in hun bedrijfsbeleid in staat zijn om mogelijkheden te creëren voor het aannemen van en het realiseren van duurzame arbeidsovereenkomsten met medewerkers met beperkingen. Het gaat daarbij om de vraag op welke wijze de persoon met zijn beperkingen zijn vermogen om te werken kan realiseren en om de vraag op welke wijze organisaties ingericht moeten zijn om dit vermogen tot werken ook daadwerkelijk in arbeid om te zetten.

Het realiseren van werken naar vermogen vraagt eveneens om onderzoek gericht op de werknemer met zijn beperkingen. Het betreft daarbij zowel de vraag naar het vaststellen van de mogelijkheden als de wijze waarop die mogelijkheden daadwerkelijk gerealiseerd kunnen worden. Onderzoek zal gericht zijn op het ontwikkelen en toetsen van methodieken om de arbeidsmogelijkheden van mensen met een beperking vast te stellen. Veel assessments gaan nog steeds uit van het vaststellen van beperkingen, terwijl vanuit een inclusieve benadering de feitelijke vraag moet zijn: welke ondersteuning is noodzakelijk opdat iemand met een beperking naar vermogen in deze samenleving kan participeren en werken.

Onderzoekzal ook gericht moeten zijn op de wijze waa rop de arbeidsmarkt het mogelijk maakt om het vermogen tot werken te realiseren. Daarbij speelt naast het herontwerp van functies ook de cultuur van de organisatie een rol, net zoals de stijl van leidinggeven en de onderlinge verhoudingen. De vraag is welke organisatiekenmerken een dergelijk veranderingsproces naar inclusieve organisaties ondersteunen en welke factoren een dergelijk proces belemmeren. De verdere ontwikkeling van de methode van inclusief herontwerp en de factoren die een rol spelen bij het implementeren van een dergelijke methodiek zullen de komende jaren een belangrijke plaats innemen in het onderzoek.

Tenslotte zal een deel van het onderzoek gericht zijn op de begeleiding naar en in werk van mensen met een beperking. In de afgelopen jaren is een inventariserend onderzoek gedaan naar de kwaliteit en wetenschappelijke onderbouwing van een groot aantal re-integratiemethodieken. Het resultaat van dit onderzoek is dat er geen wetenschappelijke evidentie is over welke methodieken voor welke specifieke groepen werknemers met een beperking succesvol zijn. Gelet op het belang van een goede toeleiding en begeleiding zowel voor de werknemer met beperkingen als voor de werkgever zal gericht evaluatie- 
onderzoek naar re-integratiemethodieken noodzakelijk zijn.

Met andere woorden er is genoeg werk te doen en ik zal doen wat in mijn vermogen ligt om de wetenschappelijke kennis op het gebied van de inclusieve arbeidsorganisatie te vergroten.

\section{Betekenis voor het onderwijs}

Om het maatschappelijk nut van bovenstaand onderzoek te vergroten zal de verworven kennis vertaald moeten worden in onderwijs en opleidingen. Onderwijsontwikkeling in het verlengde van deze leerstoel zal vooral gelegen zijn in het ontwikkelen van Masteronderwijs, en in het vormgeven van vervolgonderwijs voor professionals om hun competenties gericht op het plaatsen van mensen met beperkingen in de reguliere arbeid, te vergroten.

\section{Dankwoord}

Aan het einde van deze openbare les wil ik graag nog enkele woorden van dank uitspreken. Ik bedank het College Van Bestuur van de Universiteit Maastricht en de Faculty of Psychology and Neuroscience voor het in mij gestelde vertrouwen. Ook dank ik de Atlant groep voor het feit dat zij deze leerstoel mogelijk hebben gemaakt en daarmee een belangrijke bijdrage willen leveren aan het verwetenschappelijken van het handelen binnen de Sociale Werkvoorziening. En natuurlijk ook de leden van de klankbordgroep die mij de komende jaren kritisch zullen begeleiden binnen de gekozen paden.

Ik heb al veel jaren binnen de universiteit van Maastricht werkzaam mogen zijn in veel verschillende vak- of capaciteitsgroepen. In elke vakgroep zaten medewerkers die mij al dan niet bewust beïnvloed hebben, echter teveel om op te noemen zonder een aantal mensen tekort te doen. Voor ik overstapte naar Work and Social Psychology, was ik werkzaam vanuit Sociale Geneeskunde. Met name in deze groep zat en zit een aantal bevlogen onderzoekers en onderwijsmakers op het gebied van Arbeid en Gezondheid. Hen ben ik dan ook met name dankbaar voor hun inzet en voor de wijze waarop zij ook na mijn vertrek het onderzoek en het onderwijs op dit terrein weten te borgen. Angelique, Inge, Nicolle, Mirjam, Kees, Rineke, Nicole, Katarina....bedankt. Ik heb in de afgelopen jaren ook met onderzoekers uit andere groepen samengewerkt, daarvan wil ik er twee noemen: Agnes en Lineke, jullie ook bedankt. Het onderzoek naar secundaire beperkingen heeft voor mij nieuwe gezichtspunten opgeleverd, waardoor we beter in staat waren 
om te begrijpen wat er zich in het re-integratieproces afspeelt.

Binnen Work and Social psychology kwam ik opnieuw te werken met voor een deel nieuwe collega's en voor een deel collega's waarmee ik al langer gewerkt had. De overgang voelde onmiddellijk vertrouwd en ik denk dat er nu een goede onderzoekskern zit op het gebied van factoren die van invloed zijn op het realiseren van de arbeidsvermogens van mensen met een beperking.

Natuurlijk gaat er een extra woord van dank uit naar Fred en Henny. Fred en Henny, samen met jullie en natuurlijk ook met Gemma, Marieke en Alicia, hebben we de basis gelegd voor het innovatief herontwerp van werkprocessen. Ook de komende jaren zullen we daarop gezamenlijk veel ontwikkelingswerk en onderzoek blijven doen. Deze methodiek wordt nu uitvoerig getest in het Slotervaart Ziekenhuis in Amsterdam, dit zou nooit kunnen zonder de betrokkenheid van een groot projectteam dat verantwoordelijk is voor de implementatie van deze nieuwe methodiek. Vandaar dat mijn dank ook uit gaat naar al de betrokkenen in het Slotervaart Ziekenhuis, zonder jullie waren we nu niet zo ver geweest. Even weer terug naar de vakgroep waar ik nu sinds kort deel van uitmaak Fred, jij bent niet alleen voorzitter van de vakgroep waartoe ik nu behoor, maar ook ben jij een goede sparringpartner en praatpaal als het gaat om het onderzoek naar participatie van mensen met een beperking, ik denk dat jouw ondersteuning een grote stimulans is voor het onderzoek op dit thema. Maar natuurlijk wil ik ook mijn nieuwe collega's bedanken want zij hebben mij direct geaccepteerd en heb ik mij altijd thuis gevoeld in de nieuwe vakgroep en natuurlijk Mariëlla bedankt als steunpilaar bij alles wat gedaan moet worden.

Natuurlijk ben ik ook veel dank verschuldigd aan het thuisfront. Op de eerste plaats Brigitte, mijn inhoudelijke sparringpartner als het gaat over jongeren met een beperking en werk, maar je weet dat je nog veel meer voor mij betekent.

En natuurlijk mijn en onze kinderen: Jules, Margot, Michiel, Ghislaine, Alda en Bas. Julie leveren altijd weer de energie op om door te gaan met werk, zonder jullie zou het leven lang niet zo inspirerend zijn geweest. En ten slotte wil ik $u$ allen van harte bedanken dat $u$ bij deze openbare les aanwezig hebt willen zijn.

Ik heb gezegd 


\section{Referenties}

Borghouts I. , Pas I. van der en F. Pennings (2008). Arbeidsparticipatie van jonggehandicapten, een onderzoek naar Europese systemen en praktijken.

Tilburg: OSA

Bricout J. en K. Bentley(2000). Disability status and perceptions of employability by employers. Social Work Research, 87-95

Bruyère S.M., Erickson W. en J. Ferrentino (2003). Identity and disability in the workforce. William Mary Law Review, 1173 - 1196

Commissie Arbeidsparticipatie (2008). Naar een toekomst die werkt. Rotterdam

Commissie fundamentele herbezinning WSW (2008). Werken naar vermogen Den Haag

Commissie Werkend Perspectief (2006). Bouwen op vertrouwen. Den Haag: CWP

Copeland J.L. (2007). The impact of disability in the workplace: an assessment of employer attitudes toward people with disabilities and the ADA. Capella University

Corden A. en P. Thornton ( 1997). Case studies on employment of people with disabilities in small and medium sized Enterprises. Dublin: European Foundation for the improvement of living and working conditions

Dame C. Black (2008). Working for a healthier tomorrow London: TSO

Dijkgraaf E., Gravesteijn J., Mendys E., Nes P. van, Winden T. van en A. de Wit (2006) Plaatsing van WSW-ers bij reguliere werkgevers: hoe en onder welke voorwaarden? Rotterdam: SEOR

Domzal C., Houtenville A. en R. Sharma (2008). Survey of employer perspectives on the employment of people with disabilities: technical report. McLean VA: CESSI

Emery, F.E., (1959). The Characteristics of Sociotechnical Systems. London: Tavistock Institute

Fraser R.T., Johnson K., Hebert, J., Ajzen I., Copeland J., Brown P. en F. Chang (2009 Understanding employers hiring intentions in relation to qualified workers with disabilities: preliminary findings

Graffman J., Shinkfield A., Smith K. en U. Polzin (2002). Factors that influence employer deciscions in hiring and retaining an employee with a disability Journal of Vocational Rehabilitation, 175 -181 
Griffin, C. en D. Hammis, (2003). Making Self-Employment Work for People With Disabilities. Baltimore: Brookes Publishing.

Groothoff J., Brouwer S., Bakker R., Overweg K., Schellekens J., Abma F., Nijhuis F., en B. Pierik (2008). Bimra: Beoordelen van interventies en meetinstrumenten bij re integratie naar arbeid. Groningen: RUG

Hackman, J.R., and Oldham, G.R., (1976). Motivation through the design of work: test of a theory. Organizational Behavior and Human Performance. Vol.16(2), pp. 250-279

Hal L. van, Meershoek A., Rijk A. de, Joling C. en F. Nijhuis (2009). Een rol om op te bouwen? Zelfbeeld, levensstrategieën en re-integratietrajecten van langdurig arbeidsongeschikten. Maastricht University

Hernandez B. (2010). Exploring the Costs and Benefits of Workers with Disabilities. Journal of rehabilitation, $37-45$

Hernandez B., Keys C. en F. Balcazar (2000). Employer attitudes towards workers with disabilities and their ADA employment rights : a literature review. Journal or Rehabilitation, 4-16.

Hernandez B., McDonald K., Divilbiss, M. Horin E., Velcoff J. en O. Donoso (2008). Reflection of employers on the disabled workforce: focusgroups with health care, hospitality and retail administrators . Employee Rights and Responsibilities Journal, 20, 157-164

Holwerda, A., Klink, J.J.L. van der, Groothoff, J.W. en S. Brouwer (2010). Wajong cohort in Noord-Nederland: kenmerken van Wajong-aanvragers. TBV, volume 18 , 10: $456-462$

Horssen C.P. van (2010). Meer werkplekken bij werkgevers. Literatuuronderzoek in het kader van de evaluatie en monitoring van de pilots Werken naar Vermogen, Pilot 1 Amsterdam: Regioplan

Jahoda M. (1982). Employment and unemployment: a social-psychological Analysis. Cambridge University Press

Josten, E., (2010). Minder werk voor laagopgeleiden? Ontwikkelingen in baanbezit en baankwaliteit 1992-2008. SCP, Den Haag.

Lierop, B.A.G. van (2007). Optimising strategies for integrating people with disabilities into work Hoensbroek: IRV 
Mallee L., Oostijen J., Timmerman J. en C. Wissink (2010). Meer werkplekken bij werkgevers. Tweede tussenrapportage in het kader van de evaluatie en monitoring van de pilots Werken naar Vermogen, Pilot 1. Amsterdam: Regioplan Beleidsonderzoek

Nietupski J. en S. Hamre-Nietupski (2000). A systematic process for carving supported employment positions for people with severe disabilities. J. of Developmental and Physical disabilities, 103 - 119

OECD (2010). Sickness, disability and work: Breaking the barriers. A synthesis of findings across OECD countries.

Petersen A. van, Vonk, M. en M. Bouwmeester (2004). Onbekend maakt onbemind: attitude onderzoek naar de positie van arbeidsgehandicapten op de arbeidsmarkt. Leiden Research voor beleid

Siegert J., Ceulenaere B. en M. Wilkens (2009). Overwegingen en gedrag van werkgevers bij aannamebeleid: onderzoek naar overwegingen bij het aannemen van mensen met een afstand tot de arbeidsmarkt. Rotterdam: Ecorys

Smit A.(2009). Sociaal en slim ondernemen: werken naar vermogen in reguliere bedrijven. Leiden: TNO

Taylor, F.W. (1911). The Principles of Scientific Management. New York: Harper Bros

Van Lierop B. (2008). Wat vinden bedrijven? Een peiling onder HRM'ers en P\&O'ers over het in dienst nemen van een Wajongere. Nieuwegein: KCCO

Van Lierop, B., Van Soest, K., (2008). Job carving: succesvolle aanpak om nieuwe banen te creëren. Maandblad Reïntegratie (10), 24-26

Van Soest, K., Van Lierop, B., Van der Pijl, D. en P. Crombag (2007). Methode Maakwerk: Een handleiding voor het creëren van banen voor mensen met een verstandelijke beperking. Vilans, Utrecht

Visier L. (1998). Sheltered employment for persons with disabilities. International Labour Review, 347-65

Walkowiak, A., Zijlstra, F.R.H., Nijhuis, F., \& Taris, T. (2009). Werplekken voor mensen met beperkingen. Aanzet tot methodiek. Universiteit Maastricht en Radboud Universiteit Nijmegen in opdracht van het UWV.

Wissink C.E., Mallee L. en M. van Leer (2009). Ervaringen van werkgevers met Wajongers: onderzoek onder werkgevers naar de mogelijkheden voor verbetering van de arbeidsparticipatie van Wajongers. Amsterdam: Regioplan Beleidsonderzoek 
Zijlstra F. R. H. , Mulders H. P.G. en F. J. Nijhuis (2011). Inclusieve Organisaties: Op weg naar duurzame arbeidsparticipatie TVA (accepted for publication)

Zijlstra, F.R.H., (2003). Effect van (informatie)technologie op werkdruk en stress. In: P. Ester, D. Fouarge, M. Kerkhofs \& A. Roman (Red.), ICT, Arbeid en Organisatie, pp 209-223. Amsterdam: Reed Business Information.

Zijlstra, F.R.H., Schalk, M.J.D., Roe, R.A., (1996). Veranderingen in de Arbeid: Consequenties voor Werkenden. Tijdschrift voor Arbeidsvraagstukken, Vol.12 (3): $251-263$ 
